кандидат педагогічних наук, доцент

(Національний педагогічний університет імені М. П. Драгоманова) yuramarina@gmail.com

ORCID: 0000-0002-4040-8049

\title{
ФОРМУВАННЯ ПРОФЕСІЙНОЇ КОМПЕТЕНТНОСТІ МАЙБУТНІХ ФАХІВЦІВ 3 СОЦАЛЬНОГО ЗАБЕЗПЕЧЕННЯ У ПРОЦЕСІ ФАХОВОЇ ПІДГОТОВКИ
}

У статті обтрунтовано актуальність проблеми формування професійної компетентності фахівців у сфері соиіального забезпечення. На основі аналізу наукових теоретичних досліджень і практичного досвіду визначено і представлено характеристику основних підходів до формування професійної компетентності майбутніх фахівців з сочіального забезпечення (інспекторів з сочіальної допомоги), а саме: проектувального, інтегративного та коуч-підходів. Встановлено взаємозв'язки між зазначеними підходами; доведено доцільність їх використання на різних етапах фахової підготовки інспекторів $з$ сочіальної допомоги.

Ключові слова: професійна компетентність, формування професійної компетентності майбутніх інспекторів з соиіальної допомоги, проектувальний підхід, коуч-підхід, інтегративний підхід.

Постановка проблеми дослідження. Зміни в економічній, політичній сферах української держави в останні десятиріччя, пов'язані, зокрема, зі стрімким розвитком європейських держав, зумовлюють загострення соціальних проблем, що потребує підготовки фахівців високого рівня у галузі соціального захисту населення. Хоча практична діяльність у сфері соціального забезпечення здійснюється вже досить давно, але виокремлення її в окремий напрям відбулося лише в 2007 р. Підготовка фахівців з соціального забезпечення (зокрема, інспекторів з соціальної допомоги) розпочалася, коли Постановою Кабінету Міністрів України було започатковано окремий напрям професійної підготовки "Соціальна допомога" галузі знань 1301 "Соціальне забезпечення", а з 2016 р. - "Соціальне забезпечення" галузі знань 23 "Соціальна робота".

Таким чином, становлення соціального забезпечення як професійного напряму підготовки припало на період реформування системи соціального захисту населення, пов'язаним з інтеграцією України в євро простір, що спонукає до науково-дослідних процесів формування та функціонування соціальних служб, введення критеріїв ефективності соціального забезпечення різним категоріям населення. У зв'язку з цим, набувають актуальності проблеми підготовки фахівців у цій галузі, зокрема, інспекторів з соціальної допомоги. Зауважимо, що ціла низка проблем, що виникають у процесі здійснення професійної діяльності (труднощі в адаптації до умов професійної діяльності, низький рівень конкурентоспроможності на ринку праці тощо) значною мірою пов'язана 3 недосконалістю системи професійної підготовки майбутніх фахівців сфери соціального забезпечення.

У сучасних умовах процес підготовки фахівців з соціального забезпечення потребує врахування новітніх тенденцій у сфері професійної освіти: необхідність підвищення рівня професіоналізму, соціальної та інформаційно-комунікативної компетентності, активності, мобільності майбутніх фахівців, гнучкості та відповідальності у прийнятті професійних рішень.

Зазначене зумовлює потребу у формуванні високого рівня професійної компетентності майбутніх фахівців, що забезпечить їх ефективну професійну діяльність, належний рівень конкурентоспроможності на ринку праці, сприятиме розвитку індивідуальних здібностей i можливостей, самореалізації особистості.

Аналіз актуальних досліджень. Окремі аспекти досліджуваної проблеми розглядаються у працях вітчизняних і зарубіжних науковців: теоретико-методологічні засади професійної підготовки майбутніх фахівців соціальної сфери (О. Безпалько, І. Звєрєва, А. Капська, О. Карпенко, В. Курбатов, Л. Міщик, П. Павленко, В. Поліщук, Л. Тюптя, С. Харченко, С. Холостова та ін.); питання професійної підготовки фахівців у сфері соціального забезпечення (К. Дубич, Н. Сухицька, О. Тополь, А. Ярошенко та ін.); використання компетентнісного підходу в професійній освіті (I. Бех, В. Болотов, Д. Гришин, О. Дубасенюк, С. Лісова, В. Лозова, Н. Ничкало, О. Подмазін, О. Пруцакова, В. Сєриков та ін.); проблеми формування та розвитку професійної компетентності, професіоналізму (С. Батишев, О. Вознюк, М. Кадемія, Н. Кузьміна, М. Левківський, В. Лозова, А. Маркова, Л. Семушина, Г. Хозяїнов, Н. Ярошенко та інші).

Незважаючи на вагомі результати досліджень, доводиться констатувати, що більшість 3 досліджень відноситься до розгляду проблем професійної освіти в цілому; значна увага приділяється фаховій підготовці соціальних працівників і соціальних педагогів. Однак, питання, пов'язані 3 професійною підготовкою фахівців із соціального забезпечення, зокрема, формування їх професійної компетентності, 
залишаються відкритими (майже відсутній вітчизняний досвід), і потребують всебічного дослідження на науково-практичному рівні.

Мета статті: на основі аналізу наукових теоретичних досліджень і практичного досвіду визначити основні підходи до формування професійної компетентності майбутніх фахівців 3 соціального забезпечення (інспекторів з соціальної допомоги).

Виклад основного матеріалу. У Законі України "Про вищу освіту" [1] зазначено про необхідність поєднання освіти 3 наукою та практичною діяльністю 3 метою підготовки конкурентоспроможного людського капіталу для високотехнологічного та інноваційного розвитку країни, самореалізації особистості, забезпечення потреб суспільства, ринку праці та держави у кваліфікованих фахівцях.

У зв'язку із зазначеним, поняття професійної компетентності ми будемо розглядати 3 позицій акмеологічного підходу, як важливий показник професіоналізму фахівця з соціального забезпечення. Тому у контексті нашого дослідження професійна компетентність інспектора соціальної допомоги - це інтеграція суб'єктом професійної діяльності отриманих знань і вмінь (як з наукових і літературних джерел, так і з власного досвіду) в умовах професійної і непрофесійної діяльності. Ознакою компетентності $є$ особлива мобілізаційна готовність суб'єкта, як до застосування знань та вмінь у розв'язанні спеціальних і професійних завдань, так і до здобуття нових знань і вмінь, необхідних для формування власної системи професійної діяльності [2].

Науковець А. Маркова [3] виділяє наступні види професійної компетентності: спеціальна (вміння здійснювати професійну діяльність на високому рівні, здатність проектувати власний професійний розвиток); соціальна (здатність до спільної (групової, кооперативної) професійної діяльності, володіння прийомами професійного спілкування; соціальна відповідальність за результати своєї професійної діяльності); особистісна (володіння прийомами особистісного самовираження i саморозвитку); індивідуальна (володіння прийомами самореалізації і розвитку індивідуальності в межах професії, готовність до професійного зростання, здатність до індивідуального самозбереження, уникнення професійного вигорання, вміння раціонально організовувати власну діяльність). Сукупність зазначених видів компетентності $є$ показником зрілості людини у професійній діяльності, спілкуванні, становленні особистості та індивідуальності професіонала.

Компетентність, як інтегрований результат індивідуальної навчальної діяльності студентів, формується на основі оволодіння ними змістовими, процесуальними і мотиваційними компонентами. Рівень сформованості компетентності виявляється в процесі оцінювання навчальних досягнень студентів. Спираючись на праці Шарко В. [4], з врахуванням специфіки нашого дослідження, зазначимо основні функції оцінювання навчальних досягнень майбутніх фахівців сфери соціального забезпечення: контролююча (визначає рівень досягнень кожного студента, готовність до засвоєння нового матеріалу); навчальна (сприяє повторенню, уточненню й поглибленню знань, їх систематизації, вдосконаленню умінь і навичок); діагностико-коригувальна (3'ясовує причини труднощів, що виникають у студента в процесі навчання; виявляє прогалини у засвоєному, вносить корективи, спрямовані на їх усунення); стимулювально-мотиваційна (формує позитивні мотиви навчання); виховна (сприяє формуванню відповідальності, вмінь застосовувати прийоми контролю й самоконтролю, рефлексії навчальної діяльності).

Досягнення мети нашого дослідження вимагає розгляду специфіки професійної діяльності фахівців 3 соціального забезпечення.

За своєю функціональною природою соціальне забезпечення являє собою багатоплановий та трудомісткий вид професійної діяльності, пов'язаний зі сферою відносин "людина - людина", метою якої $\epsilon$ надання допомоги різним категоріям населення, що опинилися в складних життєвих обставинах. Основні обов'язки інспектора 3 соціальної допомоги, який є безпосереднім суб'єктом соціального забезпечення і реалізатором соціальної політики держави в системі соціального захисту населення, полягають у тому, щоб визначити рівень соціально-економічної забезпеченості клієнта чи групи осіб (сім’ї), надати допомогу і поставити в загальний реєстр осіб, що потребують підтримки від держави та проконтролювати цільове використання отриманої допомоги чи послуг. Таким чином, фахівець 3 соціального забезпечення має виконувати значну кількість функцій, починаючи зі збору відповідної документації, психологічного, правового, організаційно-адміністративного консультування та підтримки, до контролю за використанням виділених коштів. А це, у свою чергу, потребує засвоєння значного обсягу знань 3 різних напрямів (соціальна політика, право, соціологія, демографія, менеджмент, економіка, психологія, медицина, соціальна робота тощо), що є основою професійних вмінь для діагностування, координації, управління, фінансування складних життєвих обставин категорій населення, які потребують захисту і підтримки.

Підготовка фахівців з соціального забезпечення в такому багатосторонньому, складному за змістом та формою реалізації виді професійної діяльності не може одразу скластися і функціонувати як цілісна система, тим більше в умовах соціально-економічних перетворень в державі цілому та реформуванні галузевої системи соціального захисту України, зокрема. 
На думку науковця Дубич К. В., професійна підготовка інспекторів з соціальної допомоги передбачає іiї етапність, а саме: 1 етап - ознайомлення студентів 3 вітчизняним та міжнародним досвідом роботи в системі соціального забезпечення та захисту населення, змістом, метою та специфікою їх майбутньої професійної діяльності; 2 етап - вивчення, аналіз та систематизація нормативно-правової бази в системі соціального захисту населення, а також супровідних галузей знань (економіка, демографія, статистика, психологія, медицина, соціальна робота тощо); 3 етап - діагностика конкретних соціально-економічних проблем, їх оцінки, методів, форм, засобів та шляхів їх вирішення; прогнозування соціальноекономічного стану в цілому; 4 етап - створення навчально-методичних, науково-дослідних лабораторій, об'єднань з вивчення соціально-економічних проблем населення та з'ясування причин такого стану в суспільстві; 5 етап - організація навчального процесу на підставі взаємодоповнюючих компонентів: засвоєння знань, практична підготовка, творчий розвиток, науково-дослідна діяльність [5: 150-151].

Враховуючи зазначене, а також практичний досвід роботи щодо підготовки майбутніх фахівців соціальної сфери, ефективне формування професійної компетентності інспекторів з соціальної допомоги, на нашу думку, можливе за умови використання у процесі професійної підготовки поєднання проектувального, інтегрованого та коуч-підходу, що передбачають реалізацію принципів міждисциплінарної взаємодії, єдності теорії з практикою. Розглянемо зазначені підходи більш детально.

Сьогодні проектувальний підхід вважають однією з технологій переходу від парадигми традиційної до парадигми інноваційної освіти. У контексті аналізу сучасного стану розвитку науки й техніки особливого значення набуває ціннісний аспект проектувального підходу, що пов'язаний із впливом на різні види суспільної діяльності й практики - планування, програмування прийняття рішень, інженерні розробки, наукові дослідження тощо. Відзначається факт виходу проектування за межі традиційної конструкторської, інженерної діяльності й поширення на соціальні сфери - культуру, освіту, обслуговування [6].

Проектування є технічним терміном. Він з'явився у промислових галузях у середині ХХ століття i тепер набуває широкого вжитку при вирішенні цілого ряду проблем сучасного суспільства. Аналіз історії розвитку людства показав, що ідея проектування завжди активізувалася у періоди глобальних суспільних змін. Саме вони визначають географію і хронологію розвитку проектувальної діяльності у світовій культурі. Проектування, як особливий вид діяльності, базується на природних людських навичках створювати в уяві модель "необхідного майбутнього" (Н. Бернштейн) і втілювати ії в життя.

Філософи розглядають проектування як один із механізмів культури, здатний перетворити людину в творчу особистість. На філософському рівні проект визначається як результат духовно-перетворюючої діяльності. На діяльнісному - як результат проектування. Таким чином, проектування - це органічна, природна для людини діяльність.

У контексті нашого дослідження, враховуючи інтерпретацію викладачів Інституту комп'ютерних технологій США [6], проектувальний підхід дає змогу розглядати створення прообразу бажаного об'єкта, явища чи процесу з використанням спеціально відібраних методів та $\epsilon$ ланкою, що утворює зв'язки між прогнозуванням і плануванням шляхів досягнення цілей навчального процесу. Зазначений підхід спрямований на розвиток у студентів критичного мислення, вмінь самостійно здобувати та конструювати свої знання, усвідомлювати важливість набутих знань та умінь для подальшого використання їх у процесі навчання та майбутній професійній діяльності, що є необхідними умовами для формування їх професійної компетентності.

Базовим елементом проектувального підходу $\epsilon$ метод проектів, через використання якого відбувається реалізація принципу міжпредметних зв'язків, що сприяє розвитку всіх структурних компонентів професійної компетентності (змістових, процесуальних, мотиваційних), а отже, забезпечує ііі успішне формування.

Використовувати метод проектів доцільно вже з першого етапу фахової підготовки студентів, поступово ускладнюючи мету і завдання. На четвертому і п'ятому етапах фахової підготовки студенти вже можуть створювати соціальні проекти з врахуванням особливостей своєї спеціальності.

Соціальний проект призначається для відображення майбутнього бажаного стану системи, що виникає внаслідок певних дій людей, за наявності певних фінансових, трудових, матеріальних і інших ресурсів, у тому числі інтелектуальних, пізнавальних, евристичних, ціннісних тощо. Проект являє собою різновид програми, де відображені не тільки актуальні орієнтири, загальні завдання, а й уточнені терміни досягнення конкретних завдань, скоординовані зусилля виконавців на основі глибокого вивчення початкового рівня розвитку об'єкта і використання соціальних нормативів.

Алгоритми вирішення соціальних проблем базуються на основних принципах проектування: наукового обгрунтування; соціальної доцільності і цілевідповідності (відповідність очікуваних результатів нормативним (ціннісним) цілям суспільного розвитку); відповідності змін, що проектуються, фізіологічній, психічній і соціальній природі людини; комплексності, інтегративності, співставлення різних видів моделей; реалістичності і можливості для реалізації (адекватна постановка цілей, опора на наявні соціальні ресурси) [7: 65-66]. 
Зауважимо, що у процесі фахової підготовки майбутніх інспекторів з соціальної допомоги, метод проектів має використовуватися в органічній єдності з іншими методами навчання, в тому числі й 3 традиційними. Важливо підкреслити, що традиційне навчання закладає в студентів нормативне знання, яким повинен володіти кожен студент. Метод проектів вчить пошуку й використанню знань в умовах динамічної ситуації, розвиваючи гнучкість, критичність, самостійність мислення. Проте ефективність його використання залежить від наявності необхідного нормативного скелета знань, умінь і навичок, на основі яких студент здобуває нові знання, оволодіває новими вміннями.

Формування складових професійної компетентності, зокрема, особистісного та індивідуального видів, посилює використання коуч-підходу, що логічно доповнює проектувальний через встановлення суб'єктсуб'єктних взаємовідносин між викладачем та студентом, завдяки яким утримується зворотний зв'язок у формі обміну інформацією. Коуч-підхід доцільно використовувати під час практичної підготовки майбутніх фахівців, що забезпечить реалізацію принципу єдності теорії з практикою.

Розглянемо зазначений підхід до формування професійної компетентності інспекторів 3 соціальної допомоги більш детально.

Термін "коучінг" був введений на початку 90-х років англійським бізнесменом і консультантом сером Джоном Уітмором. Його дослівний переклад: наставляти, готувати, тренувати. Одне із значень англійського слова "coach" - це "карета", "возик". Коучінг - це система, яка переміщує із зони проблеми в зону ефективного її вирішення та дозволяє побачити, відчути нові підходи й можливості розв'язання конкретної проблеми, розкрити потенціал особистості [8;9]. Існує багато визначень коучінга, але загальну характеристику можна представити у вигляді взаємодії декількох складових: партнерство; розкриття потенціалу; результативність.

У сучасній професійній педагогіці "коучінг" - це вчення, що виникло на межі психології, педагогіки, менеджменту, філософії, логіки і життєвого досвіду. Це процес, спрямований на досягнення цілей у фаховій діяльності.

Основне завдання коучінга - не передача конкретних знань, а стимулювання самонавчання, у процесі якого особистість самостійно здобуває необхідну інформацію. Таким чином, коуч-підхід поєднує в собі ключові елементи проектувального підходу, та розрахований на досягнення найближчої та довгострокової перспектив формування та подальшого розвитку професійної компетентності. Найближча перспектива передбачає формування в студентів фахових знань, умінь та навичок у процесі навчальної діяльності; дальня - використання студентами здобутих знань, умінь та навичок у подальшій професійній діяльності.

За умови використання коуч-підходу, суть якого полягає в розкритті внутрішнього потенціалу особистості і приведення в дію системи її мотивації визначається стратегія, створюються плани щодо формування професійної компетентності, забезпечується високоефективність і динамічність їі розвитку; особистість розкриває нові можливості та здібності, які збільшують ефективність самореалізації останньої у професійній діяльності. Зазначений підхід дозволяє ефективно керувати формуванням професійної компетентності студентів у процесі фахової підготовки, створює позитивну атмосферу щодо iї розвитку.

Базовим елементом формування професійної компетентності інспекторів 3 соціальної допомоги $€$ інтегративний підхід, важлива особливість використання якого - забезпечення доцільного поєднання проектувального та коуч-підходів.

У цілому, під інтеграцією (лат. integratio - відновлення, поповнення, від integer - цілий) розуміють процес і результат взаємодії елементів (із заданими властивостями), що супроводжується відновленням, встановленням, ускладненням і зміцненням істотних зв'язків між ними на основі наявної підстави, в результаті чого формується інтегрований об’єкт (система) з якісно новими властивостями, у структурі якого зберігаються індивідуальні властивості вихідних елементів [10: 340].

Зауважимо, що метод проектів і коучінг передбачають постійне використання знань і вмінь 3 різних галузей. 3 іншого боку, результати використання проектувального і коуч-підходу впливають на інтеграцію змісту професійної підготовки майбутніх фахівців. Практичний досвід враховують при складанні навчальних планів і програм підготовки фахівців зазначеної спеціальності. Інтегративний підхід до вивчення дисциплін циклів гуманітарної та соціально-економічної, фундаментальної, природничо-наукової, професійної та практичної підготовки створює основу для формування в майбутніх фахівців професійної компетентності через усвідомлення студентами численних зв'язків між дисциплінами зазначених циклів.

Таким чином, інтегративний підхід, що базується на принципі міждисциплінарності, забезпечує цілісність фахової підготовки майбутніх інспекторів.

Висновки та перспективи подальшого дослідження проблеми. Отже, враховуючи зазначене вище, резюмуємо: цілісне використання проектувального, коуч та інтегративного підходів у процесі фахової підготовки забезпечить необхідні умови для успішного формування професійної компетентності майбутніх фахівців соціального забезпечення. 
Зазначені підходи створюють концептуальну основу для розробки технології формування професійної компетентності інспекторів з соціальної допомоги, що є наступним завданням нашого дослідження.

\section{СПИСОК ВИКОРИСТАНИХ ДЖЕРЕЛ ТА ЛІТЕРАТУРИ}

1. Про вищу освіту : Закон України № 1556-VII від 01 липня 2014 року [Електронний ресурс] // Офіційний вебсайт Верховної Ради України. - Режим доступу: http://vnz.org.ua/zakonodavstvo/111-zakon-ukrayinyprovyschu-osvitu.

2. Кузьмина Н. В. (Головко-Гаршина) Предмет акмеологии / Н. В. Кузьмина. - 2-е изд., испр. и доп. - СПб. : Политехника, 2002. - 189 с.

3. Маркова А. К. Психология профессионализма / А. К. Маркова. - М., 1996. - 312 с.

4. Шарко В. Д. Методологічні засади сучасного уроку : [посібник для керівників шкіл, вчителів, працівників інститутів післядипломної освіти] / В. Д. Шарко. - Видавництво ХНТУ, 2008. - 112 с.

5. Дубич К. В. Історія і теорія соціального забезпечення в Україні та за кордоном : [навчальний посібник] / Дубич К. В. - Львів : "Магнолія 2006", 2017. - Т. 1. - 272 с.

6. Intel® Навчання для майбутнього. - К. : Вид. "Нора-прінт", 2006. - 320 с.

7. Шахрай В. М. Технології соціальної роботи : [навчальний посібник] / В. М. Шахрай. - К. : Центр навчальної літератури, 2006. - 464 с.

8. Лейблинг М. Коучинг - это просто / Майк Лейблинг, Робин Прайор. - СПб. : Питер, 2008. - 144 с. - (Серия "Практическая психология").

9. Паршиков Ю. Введение в коучинг [Электронный ресурс] / Ю. Паршиков. - 2003. - Режим доступа к журн. : http://www.coacha.ru.

10. Дичківська I. М. Інноваційні педагогічні технології : навч. посіб. [для студ. вищ. навч. закл.]/ Дичківська Ілона Миколаївна. - К. : Академвидав, 2004. - 352, [2] с. - (Альма-матер).

\section{REFERENCES (TRANSLATED \& TRANSLITERATED)}

1. Pro vyshchu osvitu : Zakon Ukrainy № 1556-VII vid 01 lypnia 2014 roku [On Higher Education : Law of Ukraine № 1556-VII Dated 01 July 2014] [Elektronnyi resurs] // Ofitsiinyi veb-sait Verkhovnoi Rady Ukrainy. - Rezhym dostupu : http://vnz.org.ua/zakonodavstvo/111-zakon-ukrayiny-provyschu-osvitu.

2. Kuzmina N. V. (Holovko-Harshyna) Predmet akmeolohii [Subject of Acmeology] / N. V. Kuzmina. - 2-e izd., ispr. idop. - SPb. : Politekhnika, 2002. - 189 s.

3. Markova A. K. Psykholohiia professionalizma [Psychology of Professionalism] / A. K. Markova. - M., 1996. $312 \mathrm{~s}$.

4. Sharko V. D. Metodolohichni zasady suchasnoho uroku [Methodological Bases of the Modern Lesson] : [posibnyk dlia kerivnykiv shkil, vchyteliv, pratsivnykiv instytutiv pisliadyplomnoi osvity] / V. D. Sharko. - Vydavnytstvo KHNTU, 2008. - $112 \mathrm{~s}$

5. Dubych K. V. Istoriia i teoriia sotsial'noho zabezpechennia v Ukraini ta za kordonom [History and Theory of Social Security in Ukraine and Abroad] : [navchal'nyi posibnyk] / Dubych K. V. - L'viv : "Mahnoliia 2006", 2017. - T. 1. $272 \mathrm{~s}$.

6. Intel ${ }^{\circledR}$ Navchannia dlia maybutnioho [Intel ${ }^{\circledR}$ Training for the Future]. - K. : Vyd. "Nora-print", 2006. - $320 \mathrm{~s}$.

7. Shakhrai V.M. Tekhnolohii sotsial'noi roboty [Social Work Technologies] : [navchal'nyi posibnyk] / V. M. Shakhrai. - K. : Tsentr navchal'noi literatury, 2006. - 464 s.

8. Leiblinh M. Kouchinh - eto prosto [Coaching Is Simple] / Mayk Leyblynh, Robyn Prayor. - SPb. : Piter, 2008. 144 s. - (Seriia "Prakticheskaia psikholohiia").

9. Parshykov Yu. Vvedeniie v kouchinh [Introduction to Coaching] [Elektronnyi resurs] / Yu. Parshykov. - 2003. Rezhym dostupa k zhurn. : http://www.coacha.ru.

10. Dychkivska I. M. Innovatsiini pedahohichni tekhnolohii [Innovative Pedagogical Technologies] : navch. posib. [dlia stud.vyshch. navch. zakl.] / Dychkivska Ilona Mykolaivna. - K. : Akademvydav, 2004. -352, [2] s. - (Alma-mater).

\section{Агапова М. Б. Формирование профессиональной компетентности будущих специалистов по социальному обеспечению в процессе профессиональной подготовки.}

В статье обоснована актуальность проблемы формирования профессиональной компетентности специалистов в сфере социального обеспечения. На основе анализа научных теоретических исследований и практического опыта определено и представлено характеристику основных подходов $\kappa$ формированию профессиональной компетентности будущих специалистов по сочиальному обеспечению (инспекторов по сочиальной помощи), а именно: проектировочного, интегративного и коуч-подходов.

Установлены взаимосвязи между указанными подходами; доказана иелесообразность их использования на различных этапах профессиональной подготовки инспекторов по соииальной помощи.

Ключевые слова: профессиональная компетентность; формирование профессиональной компетентности будущих инспекторов по социальной помощи; проектировочный подход; коуч-подход; интегративный подход. 


\section{Ahapova M. B. Formation of Professional Competence of the Future Social Security Specialists in the Professional Training Process.}

The article substantiates the relevance of the problem of specialists' professional competence formation in the field of social security. The professional competence of social security specialists is considered from the standpoint of the acmeological approach as an important indicator of their professionalism, which includes social, personal and individual components.

It is noted that competence as an integrated result of individual educational activity of students is formed on the basis of mastering them content, procedural and motivational components. The stages of professional training of social assistance inspectors, taking into account the specifics of their professional activities, have been identified.

Due to the analysis of scientific theoretical researches and practical experience, it was defined and presented the features of the main approaches to the formation of professional competence of future social security specialists (inspectors from social assistance), namely designing, integrative, and coaching approaches. The basic element of the designing approach is the method of projects, through which the implementation of the principle of interdisciplinary relationships is implemented, which promotes the development of all structural components of professional competence. It has been established that the coaching approach is appropriate to be used during the practical training of future specialists, which will ensure the implementation of the principle of unity of the theory with practice and will strengthen the formation of components of professional competence, in particular, personal and individual types. The peculiarity of using an integrative approach to the formation of professional competence of social assistance inspectors is to provide an appropriate combination of design and coaching approaches. Relationships between these approaches are established; the feasibility of their use at various stages of professional training of social assistance inspectors has been proved.

Key words: professional competence; formation of professional competence of future social assistance inspectors; designing approach; coaching approach; integrative approach. 